\title{
Determining a critical threshold for G6PD activity below which red blood cell response to oxidative stress is poor
}

\author{
Maria Swastika1,2®D, Alida R. Harahap ${ }^{1}$, Lydia V. Panggalo1', Sri Widia A. Jusmann ${ }^{2,3}$ and Ari W. Satyagraha1*
}

\begin{abstract}
Background: Glucose-6-phosphate dehydrogenase (G6PD) deficiency is the most common enzyme disorder in the world. Its main function is to generate NADPH that is required for anti-oxidative pathway in the cells especially in red blood cells (RBC). G6PD deficiency is X-linked and thus subject to random X-chromosome inactivation in women giving them mosaic expression of G6PD activities in their individual cells. This phenomenon makes it difficult for diagnosis with the currently available G6PD qualitative diagnostic tests. With the rolling out of newly marketed antimalarial drug tafenoquine, which has a long half-life, screening for G6PD deficiency becomes a necessity where those with $<70 \%$ G6PD activity cannot receive this drug. Thus, evidence for a quantitative cut-off for G6PD activity is needed to ensure safe drug administration.
\end{abstract}

Methods: RBC models were developed to analyse the effect of oxidant on RBC oxidative markers namely total glutathione (GSH)and malondialdehyde (MDA). G6PD activity was measured using quantitative assay from Trinity Biotech and was correlated with cytofluorometric assay. RBC from two G6PD heterozygous women with different G6PD activities were also analysed for comparison.

Results: There was a negative correlation between G6PD activity and $\mathrm{CuCl}$ concentration and a strong association between G6PD activities and proportion of G6PD normal RBC in CuCl-treated models and in ex vivo RBC. However, in terms of oxidative stress markers analyses, unlike the hypothesis where the lower G6PD activity, the higher MDA and the lower GSH level, the CuCl RBC model showed that in low G6PD activities (10-30\%) cells, the MDA level is lower compared to the rest of the models $(p<0.05)$. The ex vivo models however were in line with the hypothesis, although the result was not significant $(p=0.5)$. There was a significant difference between $\mathrm{RBC}$ with $<60 \%$ and those with $>80 \%$ G6PD activities in CuCl RBC model, but not in ex vivo RBC ( $p=0.5)$. Genotyping heterozygous subjects showed G6PDViangchan variant with $2.97 \mathrm{U} / \mathrm{gHb}$ (33\% activity) and $6.58 \mathrm{U} / \mathrm{gHb}$ (74\% activity).

Conclusions: The GSH analysis has pointed to the 60\% G6PD activity cut-off and this data is supportive of the old World Health Organization threshold for intermediate upper limit of 60\% G6PD activity. However, there are significant limitations in using MDA assay with $\mathrm{CuCl}$ RBC model because the RBC was already stressed due to the copper treatment and thus present a different result when compared to the ex vivo model.

Keywords: G6PD deficiency, Glutathione, Heterozygous women, Malondialdehyde, Oxidative stress, Diagnostic

*Correspondence: ari@eijkman.go.id

${ }^{1}$ Red Blood Cell Enzymes and Membrane Disorders Laboratory, Eijkman Institute of Molecular Biology, Jakarta 10430, Indonesia

Full list of author information is available at the end of the article

\section{Background}

Glucose-6-phosphate dehydrogenase (G6PD) is a housekeeping enzyme that acts as a rate limiting enzyme in the pentose phosphate pathway. It generates NADPH which is required for downstream anti-oxidative activity

c) The Author(s) 2020. This article is licensed under a Creative Commons Attribution 4.0 International License, which permits use, sharing, adaptation, distribution and reproduction in any medium or format, as long as you give appropriate credit to the original author(s) and the source, provide a link to the Creative Commons licence, and indicate if changes were made. The images or other third party material in this article are included in the article's Creative Commons licence, unless indicated otherwise in a credit line to the material. If material is not included in the article's Creative Commons licence and your intended use is not permitted by statutory regulation or exceeds the permitted use, you will need to obtain permission directly from the copyright holder. To view a copy of this licence, visit http://creativeco mmons.org/licenses/by/4.0/. The Creative Commons Public Domain Dedication waiver (http://creativecommons.org/publicdomain/ zero/1.0/) applies to the data made available in this article, unless otherwise stated in a credit line to the data. 
in glutathione (GSH) cycle. G6PD deficiency is the most common enzymopathy in the world, affecting more than 400 million people; most are living in malaria endemic countries. G6PD deficiency is caused by a functional mutation of the enzyme, making it unstable and less able to form dimers or tetramers thus decreasing enzyme activity [1]. Clinical manifestations of G6PD deficiency vary widely from mostly asymptomatic to chronic anaemia (non-spherocytic haemolytic anaemia). The deficiency is defined according to the 1967 World Health Organization (WHO) enzyme classification. Class I as the most severe and chronically anaemia; class II as severe and class III as intermediate; and class IV as normal [2].

G6PD deficiency is an X-linked disorder and thus deficient males and homozygous deficient women will exhibit the full extent of the deficiency whereas G6PD heterozygous women will have a range of G6PD activities from deficient to very normal G6PD activity. This is due to random $\mathrm{X}$-inactivation that occurs very early on in the epiblast during gastrulation in individual cells [3-6] creating genetic mosaicisms among G6PD heterozygous women with the same gene mutation [4]. These mosaicisms give rise to variable G6PD activities and are thus very difficult to diagnose with the currently available qualitative diagnostic tests. Current qualitative tests can only detect $<30 \%$ G6PD activities. Previous studies have shown that the heterozygous women with G6PD activities between 30 and $80 \%$ of normal are the most difficult to diagnose since they may give 'normal' results, and yet, they can still haemolyse upon exposure to oxidative agents such as drugs (anti-malarial primaquine), food (fava beans) and infections [7-9]. Single-dose tafenoquine, another 8-aminoquinoline drug, has recently been approved by FDA (United States Food and Drug Administration) as another radical cure for malaria, aside from primaquine [10]. Because of the long half-life of tafenoquine, screening for G6PD must be done prior to giving the drug to malaria patient. To avoid the potential harmful side effect of the drug to G6PD deficient individuals, those with G6PD activity $\leq 70 \%$ of normal should not receive this drug and this includes G6PD heterozygous women [11].

G6PD quantitative test is the only test capable of diagnosing G6PD heterozygous women [12]. However, the severity of haemolysis in relation to the quantitative result when exposed to oxidative stress is unknown in these women. Oxidative stress is an imbalanced condition between the level of oxidant and antioxidant. Normally, cells have the abilities to maintain the redox equilibrium of oxidant and antioxidant level [13-15]. However, the imbalance of redox equilibrium may occur in certain conditions, such as impairment in antioxidant systems leading to oxidative stress [16, 17]. Oxidative stress in red blood cells (RBC) occur when RBC are exposed to endogenous and exogenous oxidative agents in the circulation [18]. High exposure of oxidative agents to RBC will lead to the haemoglobin oxidation to methaemoglobin and thus condense into Heinz body formations. The Heinz bodies will precipitate in the RBC membrane and become attached to cytoskeletal proteins, such as spectrin, and membrane proteins, such as Band 3. This process eventually leads to RBC membrane disruption and haemolysis or removal in the spleen $[19,20]$.

In this study, an in vitro RBC model was employed using CuClfor G6PD deficiency as described by Baird et al. [7] that were exposed to high concentration of oxi$\operatorname{dant}\left(300 \mathrm{mM} \mathrm{H}_{2} \mathrm{O}_{2}\right)$ to determine the quantitative cutoff for haemolysis. The extent of oxidative stress and degree of protection from G6PD will be measured using assays such as MDA and GSH, respectively. This result was validated in ex vivo RBC from G6PD heterozygous women having the same genotype. Knowing this cut-off value likely to result in haemolysis enables the treatment of some G6PD heterozygous women who would be likely to tolerate primaquine or tafenoquine therapy for malaria who otherwise might have been excluded because of their heterozygosity.

\section{Methods}

\section{Subjects and sample preparations}

The RBCstudies were developed from two normal males having normal G6PD activities and normal haematological profiles and two G6PD heterozygous women having normal haematological profiles. Informed consent was obtained from all subjects prior to obtaining $8 \mathrm{~mL}$ of venous blood into ACD tubes from two normal males and $2 \mathrm{~mL}$ of venous blood into EDTA tubes from two G6PD heterozygous women. Complete blood count was performed for each subject immediately after blood collection using automated haematology analyzer Cell Dyne pocH-100i (Sysmec, USA) and the blood was aliquoted accordingly for $\mathrm{CuCl}$ treatment, $\mathrm{H}_{2} \mathrm{O}_{2}$ incubation, G6PD activity measurement, flow cytometer analyses, MDA and GSH tests and were stored at $4{ }^{\circ} \mathrm{C}$ until used. Ethical clearance for the study was approved by The Ethics Committee of The Faculty of Medicine, Universitas Indonesia (No. 640/UN2.F1/ETIK/2016).

\section{Red blood cells G6PD deficiencymodels using $\mathrm{CuCl}$}

Both $\mathrm{Cu}^{+}$and $\mathrm{Cu}^{2+}$ can inhibit G6PD activity in RBC [21, 22]. Slight modification to the method previously described was made [7]. Procedures were done as soon as blood was collected where $400 \mu \mathrm{L}$ of whole blood in $\mathrm{ACD}$ was treated with $10 \mathrm{mM} \mathrm{CuCl}$ in water (Fluka, Germany) in various final concentrations of $0 \mathrm{mM}, 0.2 \mathrm{mM}$, 
0.4 mM, $0.6 \mathrm{mM}, 0.8 \mathrm{mM}, 1.0 \mathrm{mM}, 1.5 \mathrm{mM}$ and $2.0 \mathrm{mM}$ $\mathrm{CuCl}$ to mimic $10 \%, 20 \%, 30 \%, 40 \%, 50 \%, 60 \%, 70 \%$, $80 \%$ and $100 \%$ G6PD activities in heterozygous women, respectively. All samples were incubated in a $37{ }^{\circ} \mathrm{C}$ water bath for $24 \mathrm{~h}$ without shaking.

\section{G6PD quantitative test}

G6PD activity was measured for each sample after treatment with $\mathrm{CuCl}$ using quantitative test from Trinity Biotech (Trinity Biotech, Ireland) to determine the enzyme activity. The assay measured the rate of reduction of $\mathrm{NADP}^{+}$to NADPH spectrophotometrically at $340 \mathrm{~nm}$ using ultraviolet spectrophotometer (Shimadzu UVVIS 800, Japan). The rate of NADPH formation is proportional to G6PD activity. Haemoglobin was measured using HemoCue (Hemocue ${ }^{\circledR} \mathrm{Hb} 301$ System, Sweden). G6PD activity is calculated in relation to haemoglobin level in $\mathrm{U} / \mathrm{g} \mathrm{Hb}$ according to the manufacturer's manual.

\section{$\mathrm{H}_{2} \mathrm{O}_{2}$ oxidative stress treatment}

Prior to incubation with $\mathrm{H}_{2} \mathrm{O}_{2}$, the $\mathrm{RBC}$ previously treated with $\mathrm{CuCl}$, as well as the $\mathrm{RBC}$ from heterozygous G6PDsubjects and normal controls, were washed twice with phosphate buffer $\mathrm{pH}$ 8.0. Plasma and buffy coat were discarded during the washing steps. After the first wash, complete blood count was performed for all samples to calculate the amount of RBC in each sample. Final volume of $200 \mu \mathrm{L}$ of $\mathrm{RBC}$ suspension from each sample (each sample contained $10^{8} \mathrm{RBC} / 200 \mu \mathrm{L}$ suspension) was incubated with $\mathrm{H}_{2} \mathrm{O}_{2}(30 \%$, Merck, Germany) to final concentration of $300 \mathrm{mM}$ at $37^{\circ} \mathrm{C}$ for $2 \mathrm{~h}$, to induce oxidative stress in these cells. These would then be measured for glutathione and TBARS assays. Meanwhile, $\mathrm{H}_{2} \mathrm{O}_{2}$-untreated RBC from G6PD heterozygous subjects and G6PD normal controls were also incubated at $37{ }^{\circ} \mathrm{C}$ for $2 \mathrm{~h}$ alongside treated RBC samples.

\section{Malondialdehyde measurement assay}

Lipid peroxidation is an indicator of cellular damage caused by oxidative stress and MDA is a good marker of such lipid peroxidation. To measure MDA, OxiSelect TBARS Assay (Cell Biolabs, USA, Cat.\# STA-330) was used where thiobarbituric acid reactive substances (TBARS) is a rapid and direct quantitative measurement of MDA in biological samples. MDA forms a 1:2 adduct with TBA and can be measured colorimetrically. The procedure followed the manufacturer's protocol where an additional step was added to get rid of the interfering haemoglobin and its derivatives by adding $n$-Butanol. All samples and MDA standards were transferred to cuvettes including a blank control and read at $532 \mathrm{~nm}$ absorbance. All samples and standards were done in duplicates. All MDA standards were plotted into a standard curve and
MDA concentration for every sample was measured in $\mathrm{pmol} / \mu \mathrm{g}$ total protein where the protein was measured according to Lowry protein quantitation method [23].

\section{Glutathione assay}

Reduced GSH, as the major anti-oxidant in cells, especially in RBC, is normally present around $90-95 \%$ of total glutathione in the cells. Intracellular level of GSH is used as an indicator of the overall redox state of the cell. In normal cells, increased level of GSH indicates that there is an oxidative pressure within the cell. The Glutathione Assay kit (Sigma-Aldrich, Germany, Cat.\# CS0260) provides the means to measure level of total glutathione (GSSG and GSH) in a biological sample. The kit uses a kinetic assay where the catalytic amounts of GSH cause a continuous reduction of 5,5'-dithiobis(2-nitrobenzoic acid) (DTNB) to TNB and the generating GSSG is recycled by glutathione reductase and NADPH. The rate of reaction is proportional to the concentration of GSH up to $2 \mu \mathrm{M}$ where the yellow product, TNB is measured spectrophotometrically at $405 \mathrm{~nm}$ and level of GSH is measured in $\mathrm{nmol} / \mathrm{mg}$ of protein in the sample as stated in the manufacturer's protocol with slight modification, wherein a $405 \mathrm{~nm}$ wavelength was used instead of $412 \mathrm{~nm}$.

\section{G6PD cytofluorometric assay}

Prior to treatment with $\mathrm{H}_{2} \mathrm{O}_{2}$, percentage of G6PD deficient cells were analysed cytochemically to see whether they coincided with G6PD activities. The assay involved nitrite which oxidized all oxyhaemoglobin to methaemoglobin. The methaemoglobin was reduced back to oxyhaemoglobin by glucose as substrate and Nile blue as redox catalyst. This reaction depended on NADPH and G6PD normal RBC would have oxyhaemoglobin converted faster than G6PD deficient RBC. The addition of cyanide reacted with methaemoglobin and produced cyan-methaemoglobin, while oxyhaemoglobin remained inactive. Afterward, $\mathrm{H}_{2} \mathrm{O}_{2}$ introduction generated fluorescence only in oxyhaemoglobin thus distinguishing G6PD normal from G6PD deficient RBC. Fifty $\mu \mathrm{L}$ of packed RBC was mixed with $90 \mu \mathrm{L}$ of phosphate buffer $\mathrm{pH} 8.0$ for model cells and only $10 \mu \mathrm{L}$ of packed RBC and $90 \mu \mathrm{L}$ of phosphate buffer $\mathrm{pH} 8.0$ for G6PD heterozygous subjects prior to applying the protocol from Shah et al. where the assay assessed G6PD activity at the level of individual RBC [24]. The samples were analysed in BD Acuri C6 + cytometer (BD Biosciences, USA), using setting system 10,000 total events with $\mathrm{FSC}-\mathrm{H}>30,000$ collected. Samples were excited using an Arion laser $(488 \mathrm{~nm})$ and fluorescence emission was measured in the FL1 channel ( $533 \pm 30 \mathrm{~nm})$. 
DNA extraction and genotyping

DNA of G6PD heterozygous subjects were extracted using Wizard Genomic Purification DNA Kit (Promega, USA, Cat.\# A1120) with a small modification, whereas DNA isolated from $300 \mu \mathrm{L}$ of whole blood was diluted in $50 \mu \mathrm{L}$ of DNA Rehydration Solution. DNA was PCR amplified and cut at various restriction enzyme sites to detect for various known G6PD variants that are common in Indonesia [25, 26]. The fragments of PCR/ RFLP product were then analysed using agarose gel electrophoresis.

\section{Statistical analysis}

To measure the correlation between $\mathrm{CuCl}$ concentration and G6PD activities, we used Spearman test. Linear regression test was used to analyse the association between G6PD activities with proportion of normal $\mathrm{RBC}$ in RBC models. Wilcoxon test was used to test the significance between RBC models in MDA and G6PD activities, as well as MDA and GSH levels in heterozygous G6PD subjects. Meanwhile, Kruskal-Wallis test was performed to analyse the differences between GSH and G6PD activity in RBC models. The data analysis was completed using RStudio version R i386 3.3.1. (http:// www.rstudio.com).

\section{Results}

\section{DNA genotyping of G6PD heterozygous samples}

Various G6PD variants that are common in Indonesia were screened in two female subjects in this study. PCR/RFLP results from the 2 subjects having deficient and normal G6PD activities (33\% and 74\%, respectively) showed that they were both heterozygous for Viangchan variant $(871 \mathrm{G}>\mathrm{A})$ which fall into Class II according to WHO enzyme classification. G6PD Viangchan is a severely deficient variant [26].

\section{G6PD activities in CuCl RBC G6PD deficiency models and G6PD heterozygous subjects}

G6PD activities from samples treated with different $\mathrm{CuCl}$ concentrations were measured quantitatively using Trinity Biotech G6PD quantitative test as seen in Table 1 . The value of G6PD activity at $0 \mathrm{mM} \mathrm{CuCl}$ was set to $100 \%$ and the rest of the samples followed from 80 to 10\% G6PD activities from $0.2 \mathrm{mM}$ to $2 \mathrm{mM} \mathrm{CuCl}$, respectively. The mean value for $100 \%$ and $10 \%$ G6PD activity in $\mathrm{CuCl}$ $\mathrm{RBC}$ models were $6.72 \pm 0.48 \mathrm{U} / \mathrm{g} \mathrm{Hb}$ and $0.68 \pm 0.06$ $\mathrm{U} / \mathrm{g} \mathrm{Hb}$, respectively. The higher the $\mathrm{Cu}^{+}$, the lower the G6PD activity, as seen in Fig. 1, with $p$ value less than 0.001 where the association is negatively correlated. G6PD activities in the 2 G6PD heterozygous subjects were $2.97 \mathrm{U} / \mathrm{g} \mathrm{Hb}$ (33\% activity) and $6.58 \mathrm{U} / \mathrm{g} \mathrm{Hb}(74 \%$
Table 1 G6PD enzyme activity and proportion of normal RBC in CuCl-treated RBC model

\begin{tabular}{llll}
\hline $\begin{array}{l}\text { CuCl concentration } \\
(\mathbf{m M})\end{array}$ & $\begin{array}{l}\text { G6PD activity } \\
(\mathbf{U} / \mathbf{g ~ H b})\end{array}$ & $\begin{array}{l}\text { G6PD activity } \\
(\%)\end{array}$ & $\begin{array}{l}\text { Normal } \\
\text { RBC (\%) }\end{array}$ \\
\hline 0 & $6.72 \pm 0.48$ & 100 & 100 \\
0.2 & $5.62 \pm 0.18$ & 80 & 89 \\
0.4 & $3.77 \pm 0.11$ & 60 & 43 \\
0.6 & $2.81 \pm 0.02$ & 50 & 34 \\
0.8 & $2.34 \pm 0.07$ & 40 & 26 \\
1 & $1.81 \pm 0.25$ & 30 & 25 \\
1.5 & $1.30 \pm 0.27$ & 20 & 11 \\
2 & $0.68 \pm 0.06$ & 10 & 12 \\
\hline
\end{tabular}

a Data was presented in mean \pm SD

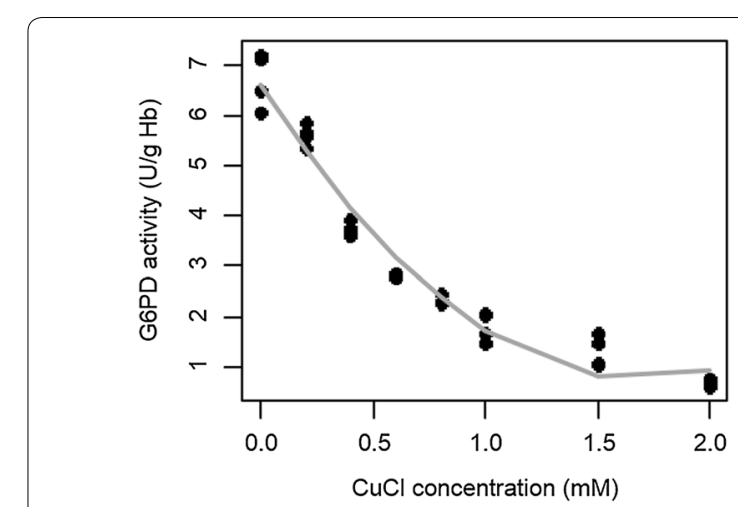

Fig. 1 Correlation between $\mathrm{CuCl}$ concentration and G6PD activity in RBC models $(p<0.001$; Spearman test)

activity). One was considered a G6PD deficient whereas the other was considered normal according to the G6PD gold standard quantitative test even though both had the same genetic polymorphism. Both subjects had normal haemoglobin level $(12.6 \mathrm{~g} / \mathrm{dL}$ and $13.1 \mathrm{~g} / \mathrm{dL})$ and normal complete blood count.

\section{Proportion of normal RBC in RBC models and G6PD heterozygous subjects}

The proportion of normal RBC (cells with normal activity of G6PD) in models and in G6PD heterozygous subjects were analysed cytochemically by flow cytometer. In $\mathrm{RBC}$ models from lowest to highest $\mathrm{CuCl}$ concentrations $(0-2 \mathrm{mM})$, the proportion of normal RBC were 100, 89, $43,34,26,25,11$ and $12 \%$ consecutively (Table 1 ). The results showed that the proportion of normal cells were decreased continuously with increasing $\mathrm{CuCl}$ concentrations, except for $\mathrm{CuCl}$-treated $\mathrm{RBC}$ model for G6PD with $10 \%$ activity, which has a slightly increased proportion of normal RBC compared to model with $20 \%$ activity. There was a strong association between G6PD activities and proportion of normal $\mathrm{RBC}$ inCuCl-treated $\mathrm{RBC}$ model 
analysed using linear regression test $\left(\mathrm{r}^{2}=0.92 ; \mathrm{p}<0.001\right)$ (Fig. 2). Those that were below 30\% G6PD activity had only $25 \%$ normal cells compared to those with $80 \%$ G6PD activity with $89 \%$ normal cells. Interestingly, those with $60 \%$ G6PD activity had only $43 \%$ normal cells. The proportions of normal RBC were 39\% in subject with 33\% G6PD activity, and 97\% in subject with 74\% G6PD activity (Fig. 3a). There was no significant difference $(p=0.5)$ when the normal cells in heterozygous subjects were compared to the RBC models with the closest G6PD activities (Fig. 3a).

\section{Oxidative stress markers analyses}

To analyse the extent of membrane damage in RBC, MDA was used to measure lipid peroxidation in RBC exposed to $\mathrm{H}_{2} \mathrm{O}_{2}$. The level of GSH was also measured to determine the level of oxidative stress in the RBC. Table 2 showed the result of MDA and GSH levels in CuCl-treated RBC G6PD models, in G6PD heterozygous women and in the G6PD normal controls. Theoretically, the lower the G6PD activity, the higher the MDA and the lower the GSH level because G6PD deficient RBC could not protect itself against oxidative damage. However, as shown in Fig. 4a, in CuCl-treated RBC G6PD models, this was not the case. It showed that low G6PD activities (10-30\%) had comparatively lower MDA level compared to the rest of the models $(\mathrm{p}<0.05)$.

In the ex vivo result of the G6PD heterozygous $\mathrm{RBC}$ showed the expected result where MDA level is higher in G6PD deficient RBC compared to normal G6PD activity in $\mathrm{H}_{2} \mathrm{O}_{2}$ treated $\mathrm{RBC}$ (Fig. 3b), although the result was not significantly different in both subjects $(\mathrm{p}=0.5)$. Comparing the ex vivo RBC between $\mathrm{H}_{2} \mathrm{O}_{2}$ treated and not treated cells, and deficient versus normal G6PD activity, the pattern was similar in that untreated cells have slightly less MDA compared to treated in both groups. However, the G6PD deficient RBC showed higher MDA

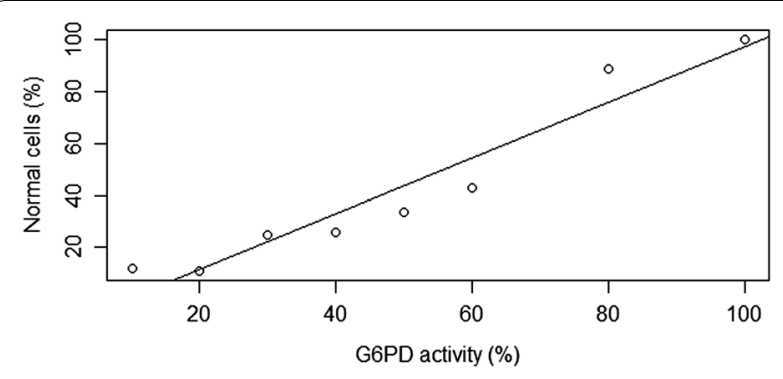

Fig. 2 Association between G6PD activities with proportion of normal RBC in $\mathrm{CuCl}$ RBC model detected by cytofluorometric assay $\left(r^{2}=0.92, p<0.001\right.$, linear regression test $)$ compared to normal RBC in both treated and untreated RBC cells.

Figure 4b showed a progressively increased GSH level from very deficient G6PD RBC to very normal G6PD $\mathrm{RBC}$ in $\mathrm{CuCl} \mathrm{RBC}$ models. There was a significant difference between RBC with $<60 \%$ G6PD activity and those with $80 \%$ and $100 \%(p<0.05)$. Similar result was found in heterozygous women in which subject with $33 \%$ G6PD activity has lower GSH level than subject with 74\% G6PD activity (Fig. 3c). Looking at the total GSH level from both groups, G6PD deficient and G6PD normal RBC, the increase of GSH level is almost twice in normal compared to deficient RBC. However, there was no significant difference of GSH level between G6PD deficient and G6PD normal RBC $(p=0.5)$ in ex vivo $R B C$. The same was observed in $\mathrm{H}_{2} \mathrm{O}_{2}$ untreated samples.

\section{Discussion}

Currently, the readily available qualitative G6PD tests can only detect $<30 \%$ G6PD activity, whereas those with activities between 30 and $80 \%$ can only be determined using quantitative G6PD test. This covers women who are G6PD heterozygous. However, the need to define a cut-off value within this $30-80 \%$ G6PD activity is needed to differentiate between severe from non-severe haemolysis when exposed to oxidant.

The $\mathrm{CuCl}$ RBC model was developed to study the effect of oxidative stress on $\mathrm{RBC}$ membrane by subjecting the cells to $300 \mathrm{mM}$ of $\mathrm{H}_{2} \mathrm{O}_{2}$ and then tried to validate the results with RBC taken from G6PD heterozygous women with the same mutation (G6PD Viangchan) but different G6PD activities where one was deficient and the other was normal according to G6PD quantitative test. Women with $74 \%$ G6PD activity would definitely be considered as normal if tested with the readily available G6PD qualitative tests. The cytochemical results positively correlated with G6PD activitiesin the ex vivo model, and thus this model can be used for oxidative stress analyses. The ex vivo RBC showed promising result that may have reflected the expected result when exposed to high concentration of oxidant unlike $\mathrm{RBC}$ model that were treated with $\mathrm{CuCl}$ prior to exposing them to $\mathrm{H}_{2} \mathrm{O}_{2}$.

In the $\mathrm{RBC}$ model treated with varying concentrations of $\mathrm{CuCl}$ to achieve different percentages of G6PD activities, the higher the enzyme activity, the higher the percentage of normal red cells (Fig. 2) as predicted [7]. However, there was a significant drop as seen in Table 1, from $80 \%$ G6PD activity with $89 \%$ normal cells to $60 \%$ G6PD activity with $43 \%$ normal cells ( $>>0.05$, was considered insignificant). It had been known that intracellular free copper was probably associated with macromolecule structures, such as DNA, enzymes and protein [27]. The over dosage of copper is toxic to cells 

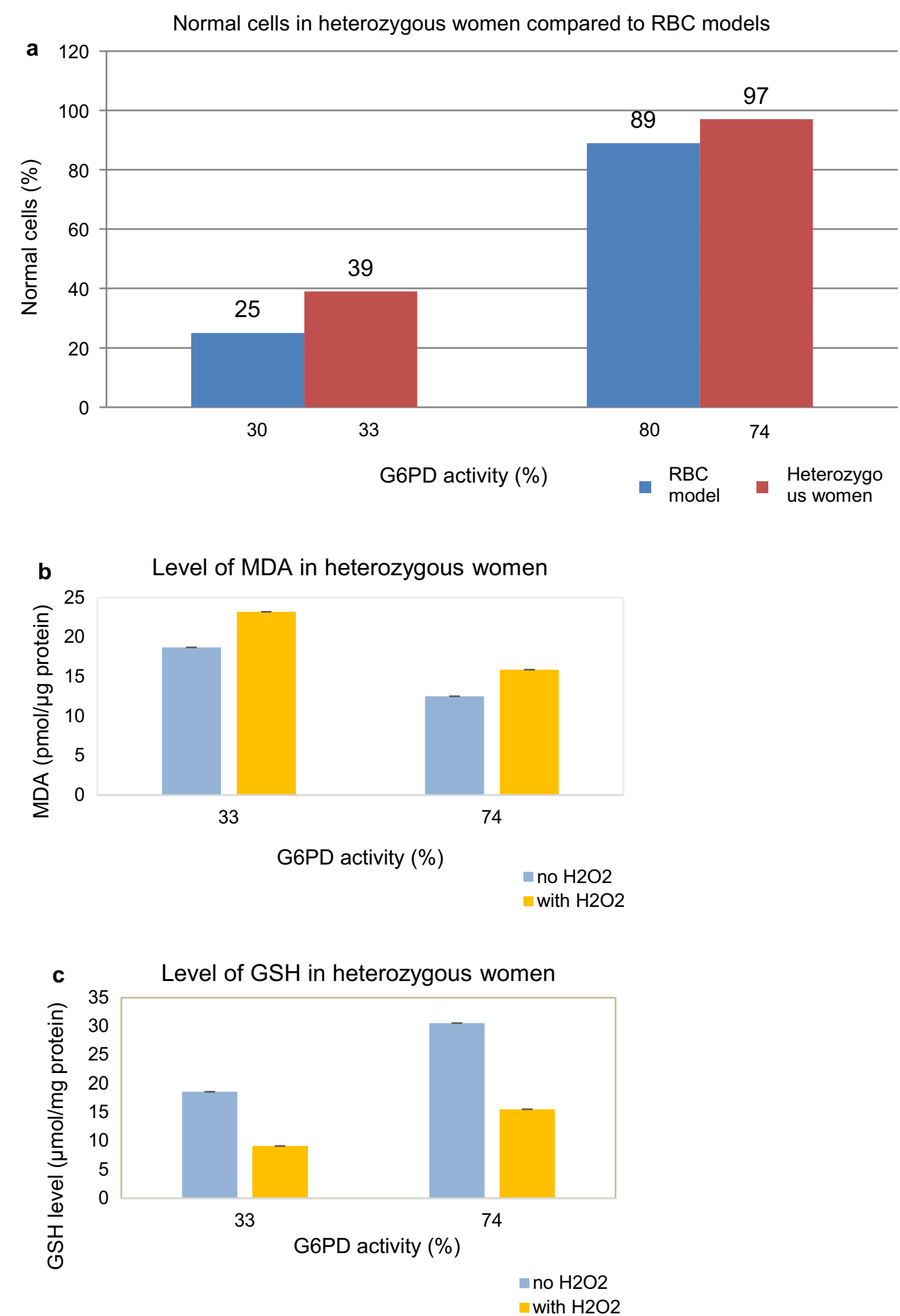

Fig. 3 Data analysis in G6PD heterozygous subjects. a Comparison between proportion of normal RBC in two different G6PD activities in heterozygous women without $\mathrm{H}_{2} \mathrm{O}_{2}$ and RBC models with closest G6PD activities. $\mathbf{b}$ Level of MDA in two different G6PD activities in heterozygous women with and without $\mathrm{H}_{2} \mathrm{O}_{2}$ ( $\mathrm{p}=0.5$, Wilcoxon test). $\mathbf{c}$ Level of $\mathrm{GSH}$ in two different G6PD activities in heterozygous women with and without $\mathrm{H}_{2} \mathrm{O}_{2}$ ( $\mathrm{p}=0.5$, Wilcoxon test). Subject 1 has 33\% G6PD activity and Subject 2 has 74\% G6PD activity 
Table 2 Level of MDA and GSH in CuCl-treated RBC model and in G6PD heterozygous women

\begin{tabular}{|c|c|c|}
\hline $\begin{array}{l}\text { G6PD activity } \\
\text { (\%) }\end{array}$ & 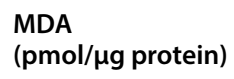 & $\begin{array}{l}\text { GSH } \\
(\mu \mathrm{mol} / \mathrm{mg} \text { protein })\end{array}$ \\
\hline \multicolumn{3}{|l|}{ RBC model $l^{a, b}$} \\
\hline 10 & $9.05(1.31-13.23)$ & $0.95 \pm 0.22$ \\
\hline 20 & $6.27(2.87-6.80)$ & $0.97 \pm 0.35$ \\
\hline 30 & $6.12(4.84-8.35)$ & $1 \pm 0.47$ \\
\hline 40 & $14.78(9.56-23.20)$ & $1.18 \pm 0.30$ \\
\hline 50 & $16.63(8.88-32.72)$ & $1.24 \pm 0.31$ \\
\hline 60 & $9.53(7.88-29.41)$ & $1.49 \pm 0.40$ \\
\hline 80 & $14.24(10.88-26.64)$ & $2.59 \pm 0.48$ \\
\hline 100 & $15.41(9.71-34.60)$ & $5.42 \pm 0.99$ \\
\hline \multicolumn{3}{|l|}{ Controls ${ }^{c}$} \\
\hline Normal-no $\mathrm{H}_{2} \mathrm{O}_{2}$ & $7.52 \pm 2.87$ & $13.76 \pm 1.26$ \\
\hline Normal- $\mathrm{H}_{2} \mathrm{O}_{2}$ & $15.18 \pm 0.32$ & $11.05 \pm 0.17$ \\
\hline \multicolumn{3}{|l|}{ Subjects ${ }^{c}$} \\
\hline Subject 1-no $\mathrm{H}_{2} \mathrm{O}_{2}$ & $18.71 \pm 3.92$ & $18.6 \pm 0.38$ \\
\hline Subject 1- $\mathrm{H}_{2} \mathrm{O}_{2}$ & $23.21 \pm 0.56$ & $9.11 \pm 0.01$ \\
\hline Subject 2-no $\mathrm{H}_{2} \mathrm{O}_{2}$ & $12.52 \pm 2.72$ & 30.54 \\
\hline Subject 2- $\mathrm{H}_{2} \mathrm{O}_{2}$ & $15.89 \pm 0.68$ & $15.51 \pm 0.24$ \\
\hline
\end{tabular}

a Data of MDA was presented in median (minimum-maximum value)

b Data of GSH was presented in mean $\pm S D$

c Data of MDA and GSH were presented in mean \pm SD

because it interferes with glycolytic enzymes, such as hexokinase and phosphofructokinase 1 , as well as other enzymes, such as phosphoglyceric kinase, 6-phosphogluconate dehydrogenase, catalase and glutathione peroxidase [21, 22, 28].

Excess copper also induces peroxidative damage in cell membranes leading to lipid bilayer destruction [29], which might explain the discrepancy of normal cells between the $80 \%$ and 60\% G6PD activity. Therefore, between 60 and $80 \%$ of G6PD enzyme activity, the drop in normal RBC is significant and thus may represent the targeted cut-off. The result of the cytochemical analysis of $\mathrm{CuCl} \mathrm{RBC}$ model above was validated in cytochemical analysis of ex vivo RBC. The ex vivo RBC showed subject with 33\% G6PD activity had only 39\% normal cells compared to subject with 74\% G6PD activity with $97 \%$ normal cells (Fig. 3a) which might indicate that those below $60 \%$ may have already lower number of normal cells compared to those $>70 \%$ as shown in RBC model (Table 1 ).

MDA represents the level of RBC membrane damage caused by oxidative stress, therefore, the lower the G6PD activity, one would expect the higher the damage and thus higher MDA level. While ex vivo RBC showed higher MDA level in G6PD deficient cells compared to normal ( $\mathrm{p}=0.5$, was considered insignificant), the $\mathrm{CuCl} \mathrm{RBC}$ model showed the opposite, i.e. lower G6PD activity and lower MDA level [22, 30]. This could be explained as before, that $\mathrm{CuCl}$ already caused oxidative stress prior to $\mathrm{H}_{2} \mathrm{O}_{2}$ treatment of the $\mathrm{RBC}$. During the $\mathrm{CuCl}$ procedure, the membrane had gone through peroxidative damage already, leaving behind less membrane lipid bilayer prior to $\mathrm{H}_{2} \mathrm{O}_{2}$ treatment. Thus, fewer MDA level was detected in the $\mathrm{CuCl}$ treated RBC model. This was skipped in ex vivo $\mathrm{RBC}$ because there was not $\mathrm{CuCl}$ treatment prior to $\mathrm{H}_{2} \mathrm{O}_{2}$ exposure.

Glutathione cycle depended on NADPH which was generated by G6PD in RBC [31, 32]. In G6PD deficient $\mathrm{RBC}$ where NADPH was reduced, the total GSH was also reduced compared to normal RBC. The total GSH would be very low so that it would not overcome oxidative stress either from $\mathrm{CuCl}$ or $\mathrm{H}_{2} \mathrm{O}_{2}$. On the contrary, in normal G6PD RBC, in the presence of oxidative stress, total GSH would be induced because there was enough NADPH produced by G6PD. These results also indicated an inversely proportional correlation between $\mathrm{CuCl}$ and $\mathrm{GSH}$ level in $\mathrm{CuCl} \mathrm{RBC}$ model. Rafter showed that leukocytes incubated with high concentration of $\mathrm{Cu}^{2+}$ decreased the reduced GSH level [33]. Previous reports by Smith et al. and Kachur et al. showed that the thiol group in GSH can be oxidized directly by copper $\left(\mathrm{Cu}^{2+}\right)$ which led to the decrease of GSH level intracellularly and thus interfere with glutathione peroxidase function in neutralizing $\mathrm{H}_{2} \mathrm{O}_{2}$ to water [34, 35].

Total GSH measurements from both $\mathrm{CuCl} \mathrm{RBC}$ model and ex vivo RBC showed that G6PD normal samples were higher than G6PD deficient samples (Figs. $3 c$ and 4 b). Figure $4 b$ showed that in RBC with 80 and $100 \%$ G6PD activity there was a significant increase of total GSH to almost double and 4 times, respectively, compared toRBC with less than 60\% G6PD activity. This suggested that cells with less than 60\% G6PD activity did not have enough NADPH to significantly increase total GSH level. Therefore, this might suggest a cut-off (at 60\% G6PD activity) in which one can use to differentiate one that is dangerously haemolytic from one that is safe when exposed to oxidant. In ex vivo $\mathrm{RBC}$, there was a $30 \%$ difference of total GSH level between subject with 33\% G6PD activity and subject with 74\% G6PD activity, and the same for both $\mathrm{H}_{2} \mathrm{O}_{2}$ treated and untreated samples which suggested that the extra 30\% GSH level was protective toward oxidative damage compared to those at lower G6PD activity as shown in MDA result. Figure 3b showed that the lower G6PD activity the higher MDA level as a marker for membrane damage. These findings were supported by other studies which explained that GSH level in normal RBC was higher than G6PD deficient-RBC [36-38]. 

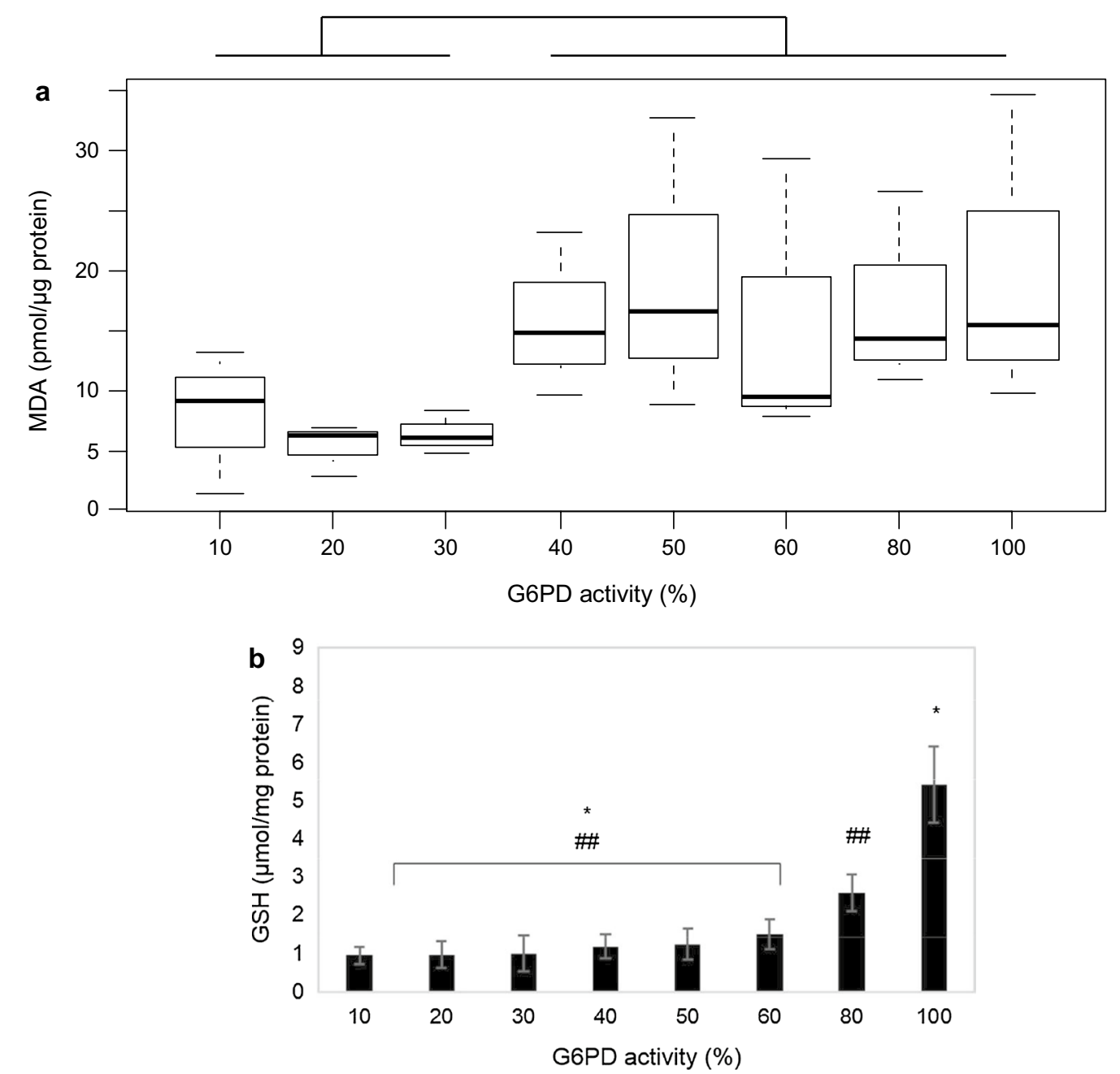

Fig. 4 Responses of $\mathrm{H}_{2} \mathrm{O}_{2}$ in RBC Models. a Level of MDA in varying G6PD activity in RBC model. Significant difference was observed between model $\leq 30 \%$ G6PD activities with model $>30 \%$ G 6 PD activities $(p<0.05$, Wilcoxon test). $\mathbf{b}$ GSH level in RBC models. Significant differences were observed between models $\leq 60 \%$ G6PD activities with models $80 \%$ and $100 \%$ G6PD activities ( $p<0.05$, Kruskal-Wallis test). ${ }^{*}$ and \#\# denote significant groups

\section{Conclusions}

The GSH studies have pointed to the $60 \%$ G6PD cutoff for severe haemolysis. However, there were limitations to this study in that more G6PD heterozygous women samples, preferably with more range of G6PD activities, were needed to be analysed to validate the G6PD deficient RBC model results. The authors admit that measuring total GSH might not be as accurate as measuring reduced GSH to determine whether oxidative stress did reduce the number dramatically in G6PD deficient cells. Haemolysis assay should be done for both in vitro and ex vivo models. From the results shown so far, it is safe to conclude that $\mathrm{CuCl}$ does have toxic effect on $\mathrm{RBC}$ on top of the overdose of $\mathrm{H}_{2} \mathrm{O}_{2}$ in $\mathrm{CuCl} \mathrm{RBC}$ model and ex vivo $\mathrm{RBC}$ and even more so in G6PD deficient RBC and thus a major limitation in this study.

\section{Abbreviations}

CuCl: Copper chloride; G6PD: Glucose-6-phosphate dehydrogenase; GSH: Total glutathione; $\mathrm{Hb}$ : Haemoglobin; MDA: Malondialdehyde; NADPH: Nicotinamide adenine dinucleotide phosphate; RBC: Red blood cells.

\section{Acknowledgements}

This study comprised the thesis for a master degree in Biochemistry and Molecular Biology at the University of Indonesia. The authors thank the volunteers who were willing to participate in this study. The authors also thank Professor Dennis Shanks of The Australian Defense Force Malaria and Infectious Disease Institute for reviewing the manuscript. 


\section{Authors' contributions}

AWS, SWAJ and ARH provided the concept and study design. MS performed all the experiments and performed the statistical analyses. MS and AWS interpreted the data. AWS and MS wrote, reviewed and edited the manuscript. SWAJ and ARH provided critical reviews on drafts of the manuscript. LVP performed the cytofluorometric assay and protein quantitation experiments. All authors read and approved the final manuscript.

\section{Funding}

This study was partially supported by The Ministry of Research, Technology and Higher Education, Republic of Indonesia.

\section{Availability of data and materials}

All data generated or analysed during this study are included in this published article.

\section{Ethics approval and consent to participate}

Ethical clearance for the study was approved by The Ethics Committee of The Faculty of Medicine, Universitas Indonesia (No. 640/UN2.F1/ETIK/2016). Informed consent was obtained from all study subjects.

\section{Consent for this publication}

Not applicable.

\section{Competing interests}

The authors declare that they have no competing interests.

\section{Author details}

${ }^{1}$ Red Blood Cell Enzymes and Membrane Disorders Laboratory, Eijkman Institute of Molecular Biology, Jakarta 10430, Indonesia. ${ }^{2}$ Master Programme in Biomedical Sciences, Faculty of Medicine, Universitas Indonesia, Jakarta 10430, Indonesia. ${ }^{3}$ Departement of Biochemistry and Molecular Biology, Faculty of Medicine, Universitas Indonesia, Jakarta 10430, Indonesia.

Received: 19 December 2019 Accepted: 29 May 2020

Published online: 17 June 2020

\section{References}

1. Luzzatto L. Glucose 6-phosphate dehydrogenase deficiency: from genotype to phenotype. Haematologica. 2006;91:1303-6.

2. Frank JE. Diagnosis and management of G6PD deficiency. Am Fam Physician. 2005:72:1277-82.

3. Ohno S, Makino $S$. The single-X nature of sex chromatin in man. Lancet. 1961:277:78-9.

4. Beutler E, Yeh M, Fairbanks VF. The normal human female as a mosaic of X-chromosome activity: studies using the gene for G-6-PD-deficiency as a marker. Proc Natl Acad Sci USA. 1962;48:9-16.

5. Goto T, Monk M. Regulation of X-chromosome inactivation in development in mice and humans. Microbiol Mol Biol Rev. 1998;62:362-78.

6. Savarese F, Flahndorfer K, Jaenisch R, Busslinger M, Wutz A. Hematopoietic precursor cells transiently reestablish permissiveness for $X$ inactivation. Mol Cell Biol. 2006;26:7167-77.

7. Baird JK, Dewi M, Subekti D, Elyazar I, Satyagraha AW. Noninferiority of glucose-6-phosphate dehydrogenase deficiency diagnosis by a pointof-care rapid test vs the laboratory fluorescent spot test demonstrated by copper inhibition in normal human red blood cells. Transl Res. 2015;165:677-88.

8. Satyagraha AW, Sadhewa A, Elvira R, Elyazar I, Feriandika D, Antonjaya $U$, et al. Assessment of point-of-care diagnostics for G6PD deficiency in malaria endemic rural Eastern Indonesia. PLoS Negl Trop Dis. 2016;10:e0004457.

9. Chu CS, Phyo AP, Lwin KM, Win HH, San T, Aung AA, et al. Comparison of the cumulative efficacy and safety of chloroquine, artesunate, and chloroquine-primaquine in Plasmodium vivax malaria. Clin Infect Dis. 2018;67:1543-9.

10. CDC. Tafenoquine approved for malaria prophylaxis and treatment. Travelers' Health. https://wwwnc.cdc.gov/travel/news-announcements/ tafenoquine-malaria-prophylaxis-and-treatment. Accessed 1 Oct 2019.
11. Rueangweerayut R, Bancone G, Harrell EJ, Beelen AP, Kongpatanakul S, Möhrle JJ, et al. Hemolytic potential of tafenoquine in female volunteers heterozygous for glucose-6-phosphate dehydrogenase (G6PD) deficiency (G6PD Mahidol Variant) versus G6PD-normal volunteers. Am J Trop Med Hyg. 2017;97:702-11.

12. LaRue N, Kahn M, Murray M, Leader BT, Bansil P, McGray S, et al. Comparison of quantitative and qualitative tests for glucose-6-phosphate dehydrogenase deficiency. Am J Trop Med Hyg. 2014;91:854-61.

13. Sies H. Biochemistry of oxidative stress. Angew Chem Int Ed Engl. 1986;25:1058-71.

14. Sies H. What is oxidative stress? In: Keaney JF, editor. Oxidative stress and vascular disease. Boston: Springer; 2000. p. 1-8. https://doi. org/10.1007/978-1-4615-4649-8_1.

15. Giustarini D, Dalle-Donne I, Tsikas D, Rossi R. Oxidative stress and human diseases: origin, link, measurement, mechanisms, and biomarkers. Crit Rev Clin Lab Sci. 2009:46:241-81.

16. Yoshikawa T, Naito Y. What is oxidative stress. JMAJ. 2002;45:271-6.

17. Scandalios JG. Oxidative stress: molecular perception and transduction of signals triggering antioxidant gene defenses. Braz J Med Biol Res. 2005;38:995-1014.

18. Srour MA, Bilto YY, Juma M, Irhimeh MR. Exposure of human erythrocytes to oxygen radicals causes loss of deformability, increased osmotic fragility, lipid peroxidation and protein degradation. Clin Hemorheol Microcirc. 2000;23:13-21.

19. Snyder LM, Fortier NL, Trainor J, Jacobs J, Leb L, Lubin B, et al. Effect of hydrogen peroxide exposure on normal human erythrocyte deformability, morphology, surface characteristics, and spectrin-hemoglobin cross-linking. J Clin Invest. 1985;76:1971-7.

20. Rifkind JM, Nagababu E. Hemoglobin redox reactions and red blood cell aging. Antioxid Redox Signal. 2013;18:2274-83.

21. Boulard M, Blume K-G, Beutler E. The effect of copper on red cell enzyme activities. J Clin Invest. 1972;51:459-61.

22. Fernandes A, Mira ML, Azevedo MS, Manso C. Mechanisms of hemolysis induced by copper. Free Radic Res Commun. 1988;4:291-8.

23. Lowry OH, Rosebrough NJ, Farr AL, Randall RJ. Protein measurement with the folin phenol reagent. J Biol Chem. 1951;193:265-75.

24. Shah SS, Diakite SAS, Traore K, Diakite M, Kwiatkowski DP, Rockett KA, et al. A novel cytofluorometric assay for the detection and quantification of glucose-6-phosphate dehydrogenase deficiency. Sci Rep. 2012;2:299.

25. Huang C-S, Hung K-L, Huang M-J, Li Y-C, Liu T-H, Tang TK. Neonatal jaundice and molecular mutations in glucose-6-phosphate dehydrogenase deficient newborn infants. Am J Hematol. 1996:51:19-25.

26. Nuchprayoon I, Sanpavat S, Nuchprayoon S. Glucose-6-phosphate dehydrogenase (G6PD) mutations in Thailand: g6PD Viangchan (871G $>A$ ) is the most common deficiency variant in the Thai population. Hum Mutat. 2002;19:185-185.

27. Gutteridge JMC, Halliwell B. The role of superoxide and hydroxyl radicals in the degradation of DNA and deoxyribose induced by a copper phenanthroline complex. Biochem Pharmacol. 1982;31:2801-5.

28. Ossola JO, Groppa MD, Tomaro ML. Relationship between oxidative stress and heme oxygenase induction by copper sulfate. Arch Biochem Biophys. 1997;337:332-7.

29. Powell SR. The Antioxidant properties of zinc. J Nutr. 2000;130:1447S-54S.

30. Ribarov S, Benov L, Benchev I, Monovich O, Markova V. Hemolysis and peroxidation in heavy metal-treated erythrocytes; GSH content and activities of some protecting enzymes. Experientia. 1982;38:1354-5.

31. Dickinson DA, Forman HJ. Cellular glutathione and thiols metabolism. Biochem Pharmacol. 2002;64:1019-26.

32. Aquilano K, Baldelli S, Ciriolo MR. Glutathione: new roles in redox signaling for an old antioxidant. Front Pharmacol. 2014;5:196.

33. Rafter GW. The effect of copper on glutathione metabolism in human leukocytes. Biol Trace Elem Res. 1982;4:191-7.

34. Smith RC, Reed VD, Hill WE. Oxidation of thiols by copper(II). Phosphorus Sulfur Silicon Relat Elem. 1994;90:147-54.

35. Kachur AV, Koch CJ, Biaglow JE. Mechanism of copper-catalyzed autoxidation of cysteine. Free Radic Res. 1999;31:23-34.

36. Osman HG, Zahran FM, El-Sokkary AMA, Sabry AM. Oxidative stress and antioxidant defense in Egyptian favism patients. Eur Rev Med Pharmacol Sci. 2013;17:1211-7.

37. Tang H, Ho H, Wu P, Chen S, Kuypers FA, Cheng M, et al. Inability to maintain GSH pool in G6PD-deficient red cells causes futile AMPK 
activation and irreversible metabolic disturbance. Antioxid Redox Signal. 2015:22:744-59.

38. Gong Z, Tian G, Huang Q, Wang Y, Xu H. Reduced glutathione and glutathione disulfide in the blood of glucose-6-phosphate dehydrogenasedeficient newborns. BMC Pediatr. 2017;17:172.

\section{Publisher's Note}

Springer Nature remains neutral with regard to jurisdictional claims in published maps and institutional affiliations.
Ready to submit your research? Choose BMC and benefit from:

- fast, convenient online submission

- thorough peer review by experienced researchers in your field

- rapid publication on acceptance

- support for research data, including large and complex data types

- gold Open Access which fosters wider collaboration and increased citations

- maximum visibility for your research: over $100 \mathrm{M}$ website views per year

At BMC, research is always in progress.

Learn more biomedcentral.com/submissions 